\title{
Peranan LAPER BE-ON (Layanan Perpustakaan On line) untuk pendidikan jarak jauh dalam era globalisasi
}

\section{Rifdah Hasan Parinduri}

\begin{abstract}
This journal discusses how be-on services (online libraries) initiated by researchers can influence distance learning which was developed as a form of adaptation to the age of globalization. This distance education requires an interactive telecommunication system to connect the two and various resources needed in it. The learning done in this distance education program is through online which specifically combines electronic technology and internet-based technology. Through this library service, students can obtain information easily and practically and can conduct meetings virtually by utilizing information technology. besides being able to meet lecture meetings with no face-to-face meetings, students can also obtain information on assignments given and can obtain books, journals or other media that can be accessed through online library services using the internet.
\end{abstract}

Keywords: Library, online, technology

\section{A. Pendahuluan}

Perpustakaan sebagai pusat sumber daya informasi yang menyediakan berbagai informasi yang dibutuhkan oleh semua kalangan, baik itu siswa, mahasiswa dan masyarakat umum. Dalam perkembangannya sendiri, perpustakaan telah mengalami perkembangan yang cukup pesat dari masa kemasa. Perpustakaan bukan hanya dikenal sebagai tempat yang menyimpan buku-buku 
tetapi sebagai layanan yang menyediakan berbagai informasi yang dibutuhkan.

Perubahan demi perubahan yang tejadi pada zaman ke zaman membuat perpustakaan beralih ke era digital. Dimana, setiap orang dapat mengakses layanan informasi dengan menggunakan internet atau layanan perpustakaan online. Layanan perpustakaan online, merupakan layanan yang menggunakan pengguna untuk memperoleh buku, jurnal, referensi yang diinginkannya. Hal ini sangatlah memudahkan pengguna untuk mendapatkan informasi secara cepat dan tidak menghabiskan waktu yang lama.

Selain itu, layanan perpustakaan online juga berperan penting dalam pendidikan jarak jauh. Pendidikan jarak jauh merupakan program yang diberikan oleh berbagai institusi atau universitas, akademi yang melakukan perkuliahan secara online.

Pendidikan jarak jauh ini telah menjadi sebuah fenomena yang berkembang di Amerika Serikat dan di seluruh dunia. Business Week Online mencatat 39 universitas yang mengadakan program pendidikan jarak jauh, sebagian besar di Amerika Serikat.

Oleh sebab itu, layanan perpustakaan online memiliki ruang lingkup yang sangat besar, bukan hanya sebatas pada peminjaman buku namun juga sebagai akses yang memudahkan di dunia pendidikan. Layanan perpustakaan online berperan penting dalam pendidikan jarak jauh, yang memungkinkan mahasiswa dan dosen untuk mengadakan pembelajaran secara virtual dengan memanfaatkan teknologi dan informasi.

Berdasarkan hal demikian, maka penulis tertarik untuk memaparkan secara lengkap mengenai "Laper Be-On (Layanan 
Perpustakaan Berbasis Online) Untuk Pendidikan Jarak Jauh Dalam Era Globalisasi”

\section{B. Pengertian Pendidikan Jarak Jauh}

Pendidikan jarak jauh merupakan pendidikan formal yang berbasis lembaga, dimana peserta didik, infrastrukturnya serta tenaga pengajarnya berada ditempat yang berbeda. Pendidikan jarak jauh ini memerlukan sistem telekomunikatif interaktif untuk menghubungkan keduanya dan berbagai sumber daya yang diperlukan didalamnya. Pembelajaran yang dilakukan dalam program pendidikan jarak jauh ini adalah melalui online yang secara khusus menggabungkan teknologi elektronika dan teknologi berbasis internet.

Kemajuan yang terjadi didunia teknologi komunikasi dan informasi memunculkan peluang maupun tantangan baru di dalam dunia pendidikan saat ini. Peluang yang muncul ialah termasuk akses yang lebih luas terhadap konten multimedia yang lebih kaya, serta berkembangnya metode pembelajaran yang kini tidak hanya dibatasi oleh ruang dan waktu, namun dapat juga dilakukan secara virtual. Namun, disisi lain kemajuan teknologi yang terus berkembang juga telah menghadirkan tantangan baru bagi penyelenggara pendidikan untuk terus menyesuaikan inftrastruktur dengan teknologi tersebut.

Pendidikan jarak jauh ini merupakan program pendidikan yang di berikan berbagai institut atau universitas dalam mengadakan perkuliahan. Perkuliahan dilakukan secara online atau setengah online. Para mahasiswa atau dosen mengadakan pertemuan secara virtual atau online. Mahasiswa pendidikan jarak jauh yang memiliki kebutuhan informasi yang besar ketika mereka 
mengerjakan penelitian. Mereka perlu mendapatkan informasi ilmiah terkini yang valid dan dapat dipercaya.

Pendidikan jarak jauh ini mulai dikenal atau berkembang di Amerika Serikat. Businnes Week Online mencatat 39 universitas yang mengadakan program pendidikan bisnis jarak jauh, sebagian besar di Amerika Serikat. Program pendidikan ini dapat berjalan lancar melalui layanan perpustakaan berbasis online. Dimana, layanan perpustakaan ini akan menyediakan berbagai kebutuhan buku, jurnal dan media lainnya yang dapat diakses melalui internet, sehingga akan memudahkan mahasiswa dalam mencari bahan tugas maupun kelas bimbingan penggunaan perpustakaan, layanan penyediaan materi cetak, indeks atau pangkalan data penelitian.

Selain itu, pendidikan jarak jauh ini juga mulai berkembang dalam berbagai ranah pendidikan. Dan berbagai negara sudah menerapkan sistem pendidikan jarak jauh ini yang berbasis layanan perpustakaan online, yang akan memudahkan mahasiswa dan dosen dalam melaksanakan pertemuan dan mengerjakan tugas-tugas yang diberikan oleh dosen.

Hemat penulis, dalam mengambil unsur pendidikan jarak jauh adalah dilatarbelakangi oleh awal berkembangnya pendidikan jarak jauh ini pertama kali dikembangkan di Amerika Serikat dan kemudian sistem ini telah diterapkan oleh beberapa negara yang ada didunia.

Adapun, secara umum pendidikan jarak jauh memiliki prinsip yang mencakup antara lain:

1. Akses, yang terkait dalam memperluas akses masyarakat terhadap pendidikan melalui penyelanggaraan pendidikan yang berbasis teknologi komunikasi dan informasi. 
2. Pemerataan yang merujuk pada dasar keadilan dan persamaan hak, bagi siapapun yang mengenyam pendidikan.

3. Kualitas, hal ini berkenaan dengan jaminan standar pengajar, materi bahan ajar dan ujian, serta proses pembelajaran yang interaktif melalui teknologi informasi dan komunikasi.

Penyelenggaraan pendidikan jarak jauh, tidak terlepas dari prinsip-prinsip yang telah disebutkan di atas. Pendidikan jarak jauh haruslah memperluas akses masyarakat terhadap penyelenggaraan pendidikan yang berbasis teknologi dan pemerataan dasar keadilan dan persamaan hak bagi pengenyam pendidikan serta kualitas atau mutu materi dan pembelajaran yang interaktif melalui teknologi.

Pendidikan jarak jauh ini merupakan salah satu bentuk perkembangan dan perubahan zaman karna adanya globalisasi. Globalisasi menuntut manusia untuk melakukan gerakan pembaharuan dalam rangka memudahkan setiap orang melakukan aktivitas, salah satunya dalam dunia pendidikan. Dengan adanya program pendidikan jarak jauh, maka hal ini akan memudahkan mahasiswa dan dosen dalam melakukan pertemuan secara virtual dengan memanfaatkan teknologi informasi dan komunikasi.

\section{Penyelenggaraan Pendidikan Jarak Jauh Di Indonesia}

Pendidikan jarak jauh yang ada di Indonesia awalnya hanya terbatas pada Universitas Terbuka yang menyediakan layanan pendidikan tanpa mengharuskan pengajar dan peserta dalam ruangan yang sama atau bertatap muka secara langsung. Namun, 
seiring dengan upaya perluasan akses pendidikan tinggi di Indonesia, pemerintah Indonesia memberikan sebuah terobosan yang mengizinkan perguruan tinggi lainnya untuk mengembangkan dan menyelenggarakan program pendidikan jarak jauh ini dengan kriteria dan persyaratan yang diatur dalam peraturan menteri pendidikan dan kebudayaan nomor 24 tahun 2012 tentang penyelenggaran pendidikan jarak jauh di perguruan tinggi.

Adapun beberapa lembaga perguruan tinggi di Indonesia yang telah melaksanakan program pendidikan jarak jauh antara lain :

1) Universitas Indonesia

2) Institut Teknologi Bandung

3) Institut Teknologi Sepuluh November

4) Universitas Gadjah Mada

5) STMIK AMIKOM Yogyakarta

6) Universitas Bina Nusantara

7) London School of Public Relations

Beberapa universitas di Indonesia telah menerapkan program pendidikan jarak jauh. Hal ini menunjukkan bahwa beberapa universitas di Indonesia telah mengadakan pembaharuan dalam hal pendidikan untuk menghadapi era globalisasi saat ini. Penulis beranggapan bahwa dengan mulai diterapkannya program pendidikan di beberapa universitas, itu merupakan suatu kemajuan bagi pendidikan di Indonesia. Penyelenggaraan pendidikan jarak jauh menjadi awal mula berkembangnya pendidikan untuk menghadapi Indonesia di Era globalisasi.

\section{Pengertian Layanan Perpustakaan}


Layanan perpustakaan pada hakikatnya adalah pemberian segala informasi kepada pemustaka perpustakaan dan penyedia segala sarana penelusuran infromasi yang tersedia di perpustakaan yang merujuk pada keberadaan sebuah informasi. Pembinaan layanan adalah suatu usaha yang dilakukan untuk memperoleh jasa atau layanan bermanfaat bagi pengguna layanan tersebut.

Berdasarkan hal ini, penulis memahami bahwa layanan perpustakaan ini merupakan usaha pemberian informasi atau penyediaan informasi yang dibutuhkan pengguna pengguna perpustakaan oleh pemustaka.

Agar dapat mencapai suatu layanan yang baik, maka dalam melaksanakan kegiatan layanan perpustakaan perlu memperhatikan asas layanan sebagai berikut :

1. Selalu berorientasi kepada kebutuhan dan kepentingan pemustaka perpustakaan.

2. Layanan yang diberikan atas dasar keseragaman, keadilan, merata, dan memandang pemustaka perpustakaan sebagai satu kesatuan yang menyeluruh.

3. Layanan perpustakaan dilandasi dengan tata aturan yang jelas dengan tujuan untuk mengoptimalkan fungsi layanan.

4. Layanan dilaksanakan dengan pertimbangan faktor kecepatan, ketepatan dan kemudahan.

Hemat penulis, jika asas pelayanan ini dapat diperhatikan dan dilaksanakan dengan baik maka pelayanan yang diberikan perpustakaan akan memberikan kenyamanan kepada pengguna perpustakaan. Sehingga, pengguna akan lebih mudah dalam mendapatkan informasi yang dibutuhkan.

Selain itu, untuk menciptakan kegiatan layanan perpustakaan yang baik, diperlukan unsur-unsur penunjang yang 
mendukung kelancaran kegiatan layanan perpustakaan. Unsurunsur tersebut harus direncanakan sesuai dengan tujuan perpustakaan dan sistem layanannya. Diantara unsur-unsurnya ialah :

1) Fasilitas

Fasilitas sebagai sarana prasarana yang harus dipenuhi oleh perpustakaan. Sarana prasarana yang memadai, bertujuan agar tujuan dan fungsi perpustakaan dapat terpenuhi.

2) Koleksi

Koleksi perpustakaan merupakan unsur utama yang harus dipenuhi dalam perpustakaan. Koleksi yang telah tersedia, haruslah dirawat, diatur secara rapi dan baik.

3) Pustakawan

Pustakawan sebagai unsur penggearak dan penyelenggara kegiatan layanan perpustakaan. Pustakawan haruslah menguasai teknologi informasi dan komunikasi.

4) Pemakai

Unsur selanjutnya dalam layanan perpustakaan adalah pemakai, yang merupakan unsur pendukung dan penentu layanan perpustakaan. Pemakai anggota masyarakat memerlukan layanan perpustakaan untuk memenuhi dan mendapatkan kebutuhan informasinya.

Hemat penulis, unsur-unsur layanan perpustakaan merupakan satu kesatuan yang saling terkait satu sama lain. Apabila unsur-unsur salah satunya tidak terpenuhi dengan baik, maka tujuan dan fungsi perpustakaan tidak dapat terlaksana dengan baik.

\section{E. Pemanfaatan Teknologi Informasi Dalam Layanan Perpustakaan}


Teknologi informasi dan komunikasi sekarang ini sangat dirasakan kebutuhan dan kepentingannya untuk perbaikan dan peningkatan kualitas pembelajaran. Melalui sistem teknologi informasi dan komunikasi memberikan jangkauan yang luas, cepat, efektif dan efesien terhadap penyebarluasan informasi keberbagai penjuru dunia. Dimana, teknologi informasi berkembang sejalan dengan perkembangan teori dan komunikasi dan teknologi yang menunjang terhadap praktik kegiatan pembelajaran.

Penulis memahami, hal ini menunjukkan bahwa teknologi informasi dan komunikasi memiliki keterkaitan peranan yang cukup signifikan terhadap dunia pendidikan, salah satu hal yang mendukung adalah dalam layanan perpustakaan. Apabila pemanfaatan teknologi informasi dan komunikasi dapat dilakukan secara maksimal, maka layanan perpustakaan akan memberikan kualitas yang memberi kepuasan pengguna. Salah satunya dalam program pendidikan jarak jauh, yang memanfaatkan teknologi informasi dan komunikasi sebagai sarana melakukan sistem pendidikan berbasis online atau digital.

Kemajuan teknologi informasi dan berkembangnya internet membuat layanan perpustakaan mengalami perkembangan yang cukup signifikan. Perkembangan layanan perpustakaan mulai beralih kepada sistem online atau sistem digital. Dalam layanan perpustakaan digital pengguna hanya memanfaatkan internet untuk memperoleh informasi ataupun mendapatkan buku-buku, jurnal yang dibutuhkan. Pemanfaatan teknologi Informasi dalam layanan perpustakaan merupakan salah satu tuntutan dari perkembangan zaman di era globalisasi saat ini. Di Indonesia, saat 
ini penggunaan layanan perpustakaan online telah diterapkan diberbagai perpustakaan besar yang ada di Indonesia. Hal ini, menunjukkan bahwa sistem layanan perpustakaan telah menunjukkan kemajuannya dari masa kemasa.

Adapun layanan perpustakaan online ini atau lebih dikenal dengan istilah perpustakaan digital,yang secara definitif perpustakaan digital menurut Arms dalam Sulistyo Basuki (2003) "Amagened collection of information, with as sociated servicesm ehere the information is stored in digital formats and accessible over a network. A crucial part of this definitions that information in managed.

Dalam pengertian itu mengandung beberapa isu sentral yang berkaitan dengan perpustakaan digital. Pertama, bagaimana mendigitalisasikan sebuah bahan atau obyek dan menyediakannya secara online. Kemudian, yang kedua bagaimana memasukkan informasi baru yang belum tersedia bentuk penyajiannya secara nyata. Dan, ketiga bagaimana menemukan bahan-bahannya serta menggunakannya dalam mengungguli teknologi dan tradisi perpustakaan.

Hal ini, penulis memahami bahwa perpustakaan digital ini memerlukan teknologi komunikasi dan informasi yang kemudian dapat tersebar ke berbagai sumber ataupun berbagai tempat. Penggunaan teknologi informasi dan komunikasi dalam layanan perpustakaan akan memudahkan setiap pengguna dalam mendapatkan informasi yang dibutuhkan. Selain itu, pustakawan juga dapat menyebar akes sumber informasi secara lebih mudah dan transparan.

Hemat penulis, jika dikaitkan dengan pendidikan jarak jauh maka pemanfaatan teknologi informasi dan komunikasi 
sangatlah penting dan berpengaruh terhadap akses pembelajaran yang dilakukan antara mahasiswa dan dosen. Melalui layanan perpustakaan ini, mahasiswa dapat memperoleh informasi secara mudah dan praktis serta dapat melakukan pertemuan-pertemuan secara virtual dengan memanfaatkan teknologi informasi.

\section{F. Layanan Perpustakaan Dalam Islam}

Layanan perpustakaan tidak terlepas dari adanya penyediaan dan pemberian informasi kepada pengguna perpustakaan. Baik itu yang manual maupun berbasis online. Perpustakaan akan menyediakan berbagai kebutuhan informasi yang dibutuhkan oleh pengguna dan haruslah dikelola dengan baik agar perpustakaan dapat terus berjalan sesuai dengan perkembangan zaman.

Dalam pandangan Islam penyediaan informasi oleh layanan perpustakaan ini berkaitan dengan kemampuan akal pikiran, manusia mempunyai naluri rasa ingin tah. Rasa ingin tahu inilah yang mendorong manusia untuk belajar meneliti rahasia Allah Swt yang ada dibumi dan dilangit. Rasa ingin tahu ini merupakan salah satu fitrah. Manusia mempunyai hak untuk tahu tentang segala sesuatu yang terjadi di alam semesta ini. Oleh karena itu manusia berhak mendapatkan atau mengakses informasi yang dikehendakinya. Manusia memerlukan informasi dalam berbagai bentuknya karena berbagai alasan. Layanan sirkulasi yang dilakukan untuk memberikan kesempatan kepada para pemakainya untuk mendapatkan informasi yang dibutuhkan Pemberian informasi atau layanan yang diberikan oleh perpustakaan merupakan aspek tolong menolong, untuk 
memudahkan pengguna dalam mendapatkan informasi yang dibutuhkan, seperti yang terdapat didalam surah Al Maidah Ayat 2 Artinya : Dan tolong menolonglah dalam mengerjakan kebaikan dan ketakwaan" (Q.S Al-Maidah: 2)

Hemat penulis, mengenai pandangan Islam terhadap layanan perpustakaan ialah bahwa perpustakaan sebagai penyedia informasi yang dibutuhkan oleh pengguna merupakan dasar yang melatarbelakangi kebutuhan setiap individu terhadap rasa ingin tahu terhadap sesuatu, yang kemudian dapat dikembangkan dalam suatu disiplin ilmu salah satunya pendidikan jarak jauh. Melalui layanan perpustakaan online, institut atau universitas dapat mengembangkan program disiplin ilmu untuk memudahkan mahasiswa dan dosen dalam melakukan pertemuan kuliah dan melakukan penelitian. Layanan perpustakaan online ini merupakan salah satu tuntutan di era globalisasi ini yang mengharuskan setiap sistem menggunakan digitalisasi dan memanfaatkan internet.

Dimana, internet merupakan sebuah jaringan global yang merupakan kumpulan dari jaringan-jaringan komputer di seluruh dunia. Internet mempermudah pemakainya untuk mendapatkan informasi-informasi didunia cyber, lembaga-lembaga miliki pemerintah dan institusi pendidikan. Pandangan Islam mengenai layanan perpustakaan berbasis online dengan menggunakan internet adalah dalam hal memenuhi kebutuhan manusia, dimana manusia sebagai insan yang memiliki sifat masih bergantung dan memiliki rasa ingin tahu dalam memperoleh pengetahuan. Melalui layanan perpustakaan online, manusia atau mahasiswa akan mendapatkan informasi yang dibutuhkannya 
secara lebih mudah dan mendapat pengetahuan dari berbagai penjuru dunia.

\section{G. Peranan Laper Be-On Dalam Pendidikan Jarak Jauh}

Layanan perpustakaan berbasis online memiliki peranan penting dalam program pendidikan jarak jauh. Pendidikan jarak jauh sebagai program yang dimiliki oleh beberapa institut atau universitas. Dimana, pendidikan jarak jauh ini dilakukan secara virtual antara mahasiswa dan dosen. Mahasiswa selain dapat memenuhi pertemuan-pertemuan perkuliahan dengan tidak bertatap muka secara langsung, juga dapat memperoleh informasi tugas-tugas yang diberikan serta dapat memperoleh buku-buku, jurnal-jurnal atau media lainnya yang dapat diakses melalui layanan perpustakaan berbasis online dengan menggunakan internet.

Adapun peranan layanan perpustakaan berbasis online dalam pendidikan jarak jauh, jika dijelaskan lebih rinci, diantaranya ialah :

a. Sebagai sarana dalam melaksanakan perkuliahan secara online atau secara virtual antara mahasiswa dan dosen. Dalam hal ini, pertemuan-pertemuan perkuliahan dapat dilakukan dengan memanfaatkan layanan perpustakaan online tanpa harus bertatap muka. Biasanya layanan perpustakaan yang digunakan adalah yang bersifat milik lembaga sendiri dan telah khusus diprogram untuk kebutuhan perkuliahan.

b. Sebagai sarana yang menyediakan berbagai bahan-bahan perkuliahan seperti, buku-buku, jurnal maupun media lainnya. Melalui layanan perpustakaan berbasis online ini, 
mahasiswa dapat memperoleh berbagai referensi yang disarankan dosen maupun yang tidak.

c. Sebagai sarana pengiriman tugas-tugas perkuliahan, dokumen-dokumen penting yang diberikan oleh dosen. Selain melakukan pertemuan perkuliahan secara virtual, layanan perpustakaan online yang dimiliki khusus bagi lembaga yang memiliki program ini, mereka dapat melakukan pengiriman atau pengumpulan tugas melalui layanan ini.

d. Mendapatkan berbagai informasi yang dibutuhkan. Layanan perpustakaan berbasis online ini juga memiliki berbagai informasi dari seluruh penjuru dunia. Informasi ini dapat diakses melalui internet dan kemudian dapat menjadi bahan dalam perkuliahan.

Berbagai poin diatas menjelaskan berbagai peranan layanan perpustakaan online dalam pendidikan jarak jauh. Hal ini, menunjukkan bahwa pemanfaatan layanan perpustakaan bukan hanya terpatok pada peminjaman dan pengembalian buku. Perpustakaan telah memiliki berbagai layanan yang dapat dengan mudah diakses oleh pengguna hanya menggunakan internet dan langsung dapat menjelajahi berbagai informasi yang dibutuhkan. Program pendidikan jarak jauh ini merupakan salah satu program yang memudahkan mahasiswa dan dosen dalam melakukan pertemuan secara virtual. Hal ini, biasanya dipengaruhi oleh beberapa faktor yang tidak memungkinkan dosen melakukan pertemuan tatap muka secara langsung, sehingga cara yang dilakukan untuk tetap mengadakan perkuliahan dengan tidak membuang waktu dan tenaga adalah melalui layanan virtual yang 
disediakan oleh program layanan perpustakaan berbasis online yang ada di lembaga pendidikan tersebut.

Hal ini, menunjukkan bahwa perkembangan teknologi informasi dan komunikasi sebagai tuntutan dari perkembangan zaman di era globalisasi ini telah membawa perubahan besar dalam dunia pendidikan saat ini. Sistem dari pendidikan yang dapat dilakukan secara virtual memudahkan setiap orang melakukan aktivitas namun tidak menurunkan nilai-nilai atau daya guna suatu aktivitas tersebut.

Dimana, pada kondisi sekarang. Teknologi infromasi dan komunikasi sudah merasuk ke segenap aspek kehidupan manusia, arus informasi menjadi sangat sulit diklasifikasikan sebagai arus informasi makro ataupun mikro. Hal ini menunjukkan bahwa perkembangan teknologi informasi dan komunikasi telah mempengaruhi berbagai aspek kehidupannya salah satunya dalam dunia pendidikan.

Hemat penulis, bahwa perkembangan layanan perpustakaan menjadi berbasis online atau memanfaatkan teknologi informasi dan komunikasi merupakan salah satu bukti nyata dari adanya globalisasi. Globalisasi telah membawa layanan perpustakaan menjadi sesuatu yang memiliki arti nilai penting bagi keberlangsungan hidup manusia. Dimana, layanan perpustakaan telah beralih menjadi berbasis online dan memiliki dampak yang penting dalam pendidikan, slaah satunya dalam pelaksanaan program pendidikan jarak jauh.

\section{H. Penutup}

Perkembangan teknologi informasi dan komunikasi sebagai akibat dari adanya globalisasi. Membuat berbagai aktivitas dari segi aspek kehidupan mengambil alih penting dalam 
keberlangsungan hidup manusia. perkembangan teknologi informasi dan komunikasi ini salah satunya berkembang dalam dunia perpustakaan. Layanan perpustakaan kini telah berkembang menjadi layanan yang memanfaatkan internet atau biasa dikenal dengan istilah layanan perpustakaan berbasis online. Layanan perpustakaan online memiliki peranan penting dalam dunia pendidikan salah satunya untuk pendidikan jarak jauh. Adapun beberapa peranan layanan perpustakaan berbasis online untuk pendidikan jarak jauh diantaranya : Sebagai sarana dalam melaksanakan perkuliahan secara online atau secara virtual, Sebagai sarana yang menyediakan berbagai bahan-bahan perkuliahan, Sebagai sarana pengiriman tugas-tugas perkuliahan, dokumen-dokumen penting, dan Mendapatkan berbagai informasi yang dibutuhkan.

Buxbaum, Shari. 2004. Library Services : Perpustakaan Virtual Untuk Kuliah Bisnis Sistem Jarak Jauh/shari Buxbaum. Jakarta : PT RajaGrafindo.

Hartono. 2016. Manajemen Perpustakaan Profesional. Jakarta : Sagung Seto.

Herlina, Pembinaan dan Pengembangan Perpustakaan. Palembang : Noer Fikri.

Pawit. 2016. Ilmu Informasi, komunikasi, dan kepustakaan, Jakarta : Bumi Aksara

Rifai, Nasib. Kemudahan Dari Allah: Ringkasan Tafsir Ibnu Katsir. Jilid 4, Jakarta : Gema Insani Press.

Rusman. 2015. Pembelajaran Berbasis Teknologi Informasi dan Komunikasi, Jakarta : Rajawali Press 